\title{
UNIVERSITY OF WISCONSIN RADIOCARBON DATES VII
}

\author{
MARGARET M. BENDER, REID A. BRYSON, \\ and DAVID A. BAERREIS
}

Department of Meteorology, University of Wisconsin, Madison

The radiocarbon dates obtained since August, 1968, are reported here. Wood, charcoal, and peat samples are pretreated with dilute $\mathrm{NaOH}$ and dilute $\mathrm{H}_{3} \mathrm{PO}_{4}$ before conversion to the methane used as counting gas; marls and lake cores are treated with acid only. The reported dates have been calculated using 5568 years as the half-life of $\mathrm{C}^{14}, 1950$ as the reference year. Samples are run at least once in each of two 0.5 liter counters at $3 \mathrm{~atm}$ pressure for a minimum total of 15,000 counts. The standard deviation quoted includes only the $1 \sigma$ of the counting statistics of background, sample, and standard counts.

In November, 1968, the laboratory was moved to a new location, the basement of a high rise building. As a result the background count at 3 atm pressures in our two counters has been reduced to $1.2 \pm 0.1 \mathrm{cpm}$. The counter efficiencies remained unchanged.

\section{ACKNOWLEDGMENTS}

This research is supported by the National Science Foundation Atmospheric Sciences Division, Grant GP-5572X1, and Social Sciences Division, Grant GS-1141.

\section{ARCHAEOLOGIC SAMPLES}

\section{A. Iowa}

\section{Rock Run Shelter series, Iowa (13CD10)}

Charcoal samples from excavations at Rock Run Shelter on a small tributary of Cedar R. in Cedar Co., Iowa $\left(41^{\circ} 42^{\prime} \mathrm{N}\right.$ Lat, $91^{\circ} 11^{\prime} \mathrm{W}$ Long). Coll. 1968 by R. Alex, State Univ. of Iowa; subm. by D. A. Baerreis. These dates supplement those reported earlier (Radiocarbon, 1969 , v. 11, p. 229).

WIS-331. Rock Run Shelter site (13CD10)

Charcoal from 22 to 24 in. depth.

WIS-328. Rock Run Shelter site (13CD10)

Charcoal, wood fragments, and nuts, from 32 to $34 \mathrm{in}$. depth.

WIS-333. Rock Run Shelter site (13CD10)

Charcoal with mud 44 to 46 in. deep.

WIS-384. Rock Run Shelter site (13CD10)

Charcoal from 50 to 52 in. depth.

$$
\begin{array}{r}
1330 \\
\text { A.D. } 620
\end{array}
$$

$1640 \pm 60$

A.D. 310

$$
2560 \pm 60
$$$$
610 \text { B.C. }
$$

$3660 \pm 60$ 1710 B.C. 
WIS-383. Rock Run Shelter site (13CD10)

Charcoal from 52 to 54 in. depth.

\section{Jackson County, Iowa (13JK20)}

Charcoal from rock shelter containing primarily Woodland occupation on Maquoketa R., Jackson Co., Iowa $\left(42^{\circ} 10 \mathrm{~N} \mathrm{Lat,} 90^{\circ} 50^{\prime} \mathrm{W}\right.$ Long). Coll. 1968 by M. Jaehnig; subm. by D. A. Baerreis.

\section{WIS-344. Jackson County, Iowa (13JK20)}

$1780 \pm 60$

Charcoal from Level 15 of Test Pit 2, 28 to 30 in. deep.

\section{WIS-345. Jackson County, Iowa (13JK20)}

$980 \pm 60$

Sample from Level 3 of Test Pit 3, 8 to 12 in. deep.

\section{B. Wisconsin}

\section{Iowa County series, Wisconsin (47IAl and 47IA38)}

Charcoal samples from 2 stratified rock shelters, Governor Dodge State Park Rock Shelter $\left(43^{\circ} 0 \mathrm{I}^{\prime} \mathrm{N}\right.$ Lat, $90^{\circ} 06^{\prime} \mathrm{W}$ Long) and Mayland Cave $\left(43^{\circ} 04^{\prime} \mathrm{N}\right.$ Lat, $90^{\circ} 08^{\prime} \mathrm{W}$ Long), excavated by Univ. of Wisconsin field school under the direction of J. B. Stoltman, Univ. of WisconsinMadison, during summer 1968. Subm. by J. B. Stoltman. Governor Dodge Rock Shelter had been tested previously by W. Wittry (1959).

\section{WIS-335. Governor Dodge State Park Rock Shelter (47IA1) \\ $1600 \pm 55$ \\ A.D. 350}

Charcoal from probable hearth in Feature 3, a dark, bone-rich layer localized within 3 five $\mathrm{ft}$ squares in NW corner of excavated area. Sample from Sq. 6, Level 4, 0.9 to $1.2 \mathrm{ft}$ deep. Since nearly all dentate rockerstamped pottery found at site was either in direct assoc. with or close to Feature 3, hearth probably is assoc. with Middle Woodland occupation of site. Date is in excellent agreement.

\section{WIS-368. Governor Dodge State Park $\quad 4170 \pm 65$ Rock Shelter (47IA1) 2220 B.c.}

Bone and charcoal from Sq. A6, Level 13, Feature 15, 3.6 to $3.9 \mathrm{ft}$ and Sq. Z6, Level 11, 3.0 to $3.3 \mathrm{ft}$ deep.

\section{WIS-367. Governor Dodge State Park $\quad 3820 \pm 65$ Rock Shelter (47IAl) \\ 1670 B.C.}

Charcoal from Sq. Z6-9, Feature 15, 2.4 to $2.7 \mathrm{ft}$ deep.

WIS-336. Mayland Cave (47IA38)

Modern

Charcoal from Feature 1, shallow, basin-shaped depression, at depth 0.9 to $1.2 \mathrm{ft}$. Feature 1 is attributed to Late Woodland occupation which appears to have been in contact with Upper Mississippian (Oneota) peoples. Date is inconsistent with archaeologic evidence. In dry sediments 
of this cave, it is likely that charcoal from historic campfires has contaminated sample as a result of burrowing rodent activity.

WIS-337. Mayland Cave (47IA38)

A.D. 1270

$680 \pm 55$

Charcoal from Feature 6e, shallow basin-shaped depression at depth 1.8 to $2.1 \mathrm{ft}$; 25 body sherds from single vessel of type Grand River Trailed were also recovered from feature. Date, acceptable for Oneota, should also apply to Late Woodland (characterized by Madison ware) occupation at site.

\section{WIS-357. Mayland Cave (47IA38)}

$$
1010 \pm 55
$$

Sample from Sq. B1, Level 5, 1.8 to $2.1 \mathrm{ft}$ deep, in Feature 17, beneath large sandstone block from roof fall. Feature consisted of concentration of charcoal, pottery, and some animal bone.

\section{WIS-369. Mayland Cave (47IA38)}

$$
1590 \pm 55
$$

Sample from Sq. B4, Level 14, 3.9 to $4.2 \mathrm{ft}$ deep. Sample immediately below distinct change in relative frequencies of various animal species that might reflect local change in vegetation cover.

\section{WIS-370. Mayland Cave (47IA38)}

$$
1630 \pm 70
$$

Charcoal from Sq. B1, Level 15, 4.8 to $5.4 \mathrm{ft}$ deep. Date should indicate time of earliest occupation of site by Late Woodland peoples.

\section{WIS-354. Hilgen Spring Park site}

$\mathbf{2 4 1 0} \pm \mathbf{5 5}$ ite site $\mathrm{O} z 7$, Cedarburg, Wisconsin $\left(43^{\circ} 17^{\prime} 30^{\prime \prime} \mathrm{N}\right.$ Lat, $87^{\circ} 58^{\prime} 30^{\prime \prime} \mathrm{W}$ Long). Mound was one of 3 conical mounds of Effigy Mound culture (Brown, 1906). Coll. 1968 by H. Van Langen; subm. by T. F. Kehoe, Milwaukee Public Mus., Milwaukee, Wisconsin.

\section{Jefferson County series (47JE244)}

Samples from the Crescent Bay Hunt Club site, an Oneota component on Lake Koshkonong, Jefferson Co., Wisconsin $\left(42^{\circ} 53^{\prime} \mathrm{N}\right.$ Lat, $89^{\circ} 00^{\prime}$ W Long) coll. 1968 by D. A. Baerreis.
WIS-346. Crescent Bay Hunt Club site (47JE244)
$760 \pm 50$
Charcoal from Feature 1. A.D. 1190
WIS-348. Crescent Bay Hunt Club site (47JE244)
Charcoal from Feature 10.
WIS-358. Crescent Bay Hunt Club site (47JE244)
A.D. 1150
$800 \pm 50$$$
780 \pm 50
$$
A.D. 1170

Charcoal from Feature 6. 


\section{WIS-382. Crescent Bay Hunt}

Club site (47JE244)

A.D. 1140

$810 \pm 50$

Charcoal from Feature 9.

\section{Nebraska}

\section{Mowry Bluff site, Nebraska (25FT35)}

Charcoal excavated 1967 by W. R. Wood, Univ. of Missouri, from Mowry Bluff site at Frontier Co., Nebraska $\left(40^{\circ} 22^{\prime} 30^{\prime \prime} \mathrm{N}\right.$ Lat, $100^{\circ} 13^{\prime}$ 12" W Long); subm. by D. A. Baerreis. Site is of Upper Republican affiliation.

WIS-318. Mowry Bluff site (25FT35)

$790 \pm 55$

Sample from Feature 19, wall post from W house wall.

WIS-319. Mowry Bluff site (25FT35)

A.D. 1180

Charcoal from Feature 32.

\section{WIS-324. Mowry Bluff site (25FT35)}

$930 \pm 60$

Charcoal from Feature 45, center post of House 1.

\section{Kansas}

WIS-326. Nuzum site, Kansas (14DP10)

$860 \pm 55$

A.D. 1090

$$
770 \pm 55
$$

Charred wood from Nuzum site, Nebraska culture site, Doniphan

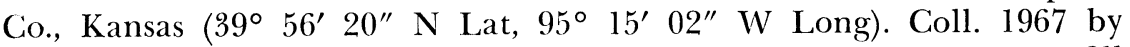
W. R. Wood; subm. by D. A. Baerreis. Sample from House 1, from fill of Feature 3, large charred post.

\section{E. Oklahoma}

MeCurtain focus, MeCurtain County (Mc-8 and Mc-104)

McCurtain focus in SE Oklahoma is quite similar to remains designated in Texas as Texarkana focus but is thought to represent a slightly earlier period (Bell and Baerreis, 1951). The Clement site (Mc-8) (ibid., p. 53-55) is one of type sites of culture.

\section{WIS-327. Clement site, Oklahoma (Mc-8)}

A.D. 1460

$$
490 \pm 55
$$

Charred corn cob from Clement site, McCurtain Co., Oklahoma (34 $04^{\circ}$ N Lat, 95 $55^{\prime} \mathrm{W}$ Long). Sample from Mound area, Grid I, Sq. 25:9, Layer 2, 64 in. deep. Coll. 1941 and subm. by D. A. Baerreis. Date includes correction of $200 \mathrm{yr}$ for $\mathrm{C}^{13} / \mathrm{C}^{12}$ isotopic fractionation (Bender, 1968).

WIS-248. Woods Mound Group, Oklahoma (Mc-104) $430 \pm 55$ A.D. 1520

Sample from Woods Mound Group, McCurtain Co., Oklahoma (34 ${ }^{\circ}$ $18^{\prime} \mathrm{N}$ Lat, $94^{\circ} 41^{\prime} \mathrm{W}$ Long). Charcoal from post which is part of 
rectangular, with rounded corners and extended entranceway, house pattern found under Mound B. Two dates were previously reported for this site, A.D. $1240 \pm 80$ (GaK-901) and A.D. $1791 \pm 147$ (SM-888), latter thought to be in error (Bell, 1968).

\section{Cooper sites (DL-48 and DL-49)}

Charcoal from Cooper site, Delaware Co., Oklahoma $\left(36^{\circ} 35^{\prime} \mathrm{N}\right.$ Lat, $94^{\circ} 50^{\prime} \mathrm{W}$ Long). Coll. 1939 and subm. by D. A. Baerreis. DL-33 and DL-49, for which dates were previously obtained are Middle Woodland components of Hopewellian affiliation. Earlier dates from this site reported (Radiocarbon, 1969, v. 11, p. 228-235) were WIS-307, -309, and -313 , A.D. 970,1270 , and 110 , respectively. DL-48 (D1CoVI) is nearby rock shelter containing both earlier and later occupations in addition to Middle Woodland zone. Dates for the Hopewellian occupation seem to be both too early and too recent for culture. Perhaps discrepant dates are due to storage of charcoal for $30 \mathrm{yr}$ without protection from contamination.

WIS-372. Cooper site (DL-49)

$3410 \pm 70$

Sample 1532 fom NE 11:6, Level 5, 20 to 24 in. deep.

WIS-379. Cooper site (DL-48)

$700 \pm 50$

Sample 379 from Sq 3:6, Level 10, 36 to 40 in. deep.

WIS-380. Cooper site (DL-48)

A.D. 1250

1460 B.c.

Sample 530 from Sq 2:3, Level 23, 88 to 92 in. deep.

WIS-385. Cooper site (DL-48)

$3000 \pm 65$ 1050 B.c.

Sample 1186 from Sq. 2:4, Level 28, 108 to 112 in. deep.

$2970 \pm 60$

1020 в.c.

\section{F. Illinois}

\section{Cahokia site, Monk's Mound}

Wood charcoal from Monk's Mound Cahokia site, Madison Co., Illinois (38 $48^{\prime} \mathrm{N}$ Lat, $90^{\circ} 04^{\prime} \mathrm{W}$ Long). Coll. 1967 and 1968 and subm. by M. Fowler, Univ. of Wisconsin-Milwaukee.

\section{WIS-359. Cahokia, Monk's Mound}

$690 \pm 5.5$

Sample $67-386$ from stockade, $\log$ assoc. with trench 40 to $70 \mathrm{~cm}$ deep at E461.64-461.70, N336.80.

WIS-362. Cahokia, Monk's Mound A.D. 1260

$690 \pm 50$

Charcoal from Feature 104, burned clay floor underneath small mound on SW corner of 1st terrace of Monk's Mound. Sample 68-459 from E112-114, N70-72, elev. $138.58 \mathrm{~m}$. 
WIS-365. Cahokia, Monk's Mound A.D. 1110

$840 \pm 55$

Wood charcoal, probably oak, from Post 2 in Feature 114, burned structure which underlies small mound on SW corner of 1st terrace of Monk's Mound. Post was standing upright in wall trench and had broken off when structure collapsed. Burned structure predates "primary" mound and post dates series of unburned living surfaces and possible post pit. Sample 68-1015 from N63.45-63.62, E100.54-100.66, $160 \mathrm{~cm}$ deep at N62E102.

WIS-366. Cahokia, Monk's Mound

A.D. 1060

$890 \pm 55$

Charcoal from post assoc. with trench, $100 \mathrm{~cm}$ deep. Sample 68-770 from E159.60-159.74, S604.38-604.50.

\section{WIS-334. Divers site (MO-28)}

$845 \pm 45$

Specimen DC 14, outer 10 rings of charred post from NE wall of Feature 1, rectangular wall-trench house at Divers site, Monroe Co., Illinois ( $38^{\circ} 27^{\prime} 42^{\prime \prime} \mathrm{N}$ Lat, $90^{\circ} 15^{\prime} 25^{\prime \prime} \mathrm{W}$ Long). Site is Mississippian variant in Lundsford-Pulcher areas of American Bottoms. Date should provide lower limit for Old Village phase in Cahokia area. Coll. 1968 by Glen A. Freimuth; subm. by James Porter, both Univ. of Winnipeg, Winnipeg, Canada.

$$
\text { II. GEOLOGIC SAMPLES }
$$

\section{A. Wisconsin}

Schimelpfenig Bog series, Dane County, Wisconsin

Samples excavated 1967 from marl layer underlying peat deposit on Elmer Schimelpfenig farm, Dane Co., Wisconsin $\left(43^{\circ} 04^{\prime} 45^{\prime \prime}\right.$ N Lat, $89^{\circ} 04^{\prime} 45^{\prime \prime} \mathrm{W}$ Long). Coll. by J. E. Dallman, Univ. of WisconsinMadison; subm. by D. A. Baerreis. Dates on mastodon bones and wood obtained in this excavation have been reported previously (Radiocarbon, 1968 , v. 10, p. 475).

\section{WIS-305. Schimelpfenig Bog, Wisconsin}

$11,720 \pm 140$ 9770 B.c.

Snail shells (Gyraulus parvus [Say]) from Sec. III, 38 to 40 in. deep. Outer $15 \%$ of shell removed by acid leaching.

\section{WIS-338. Schimelpfenig Bog, Wisconsin}

$12,870 \pm 125$

Organic clay from Col. IV, 66 to 68 in. deep. Date is minimum for deglaciation and is comparable to WIS-48 (Radiocarbon 1965, v. 7, p. 407).

\section{WIS-339. Jefferson County, Wisconsin}

$$
4270 \pm 70
$$

Black homogeneous peat from ca. $300 \mathrm{~cm}$ deep in spring mound, very near base of brganic deposit. Mound rises above glacio-lacustrine plain and is built around artesian spring in Jefferson Co., Wisconsin 
$\left(42^{\circ} 52^{\prime} \mathrm{N}\right.$ Lat, $88^{\circ} 46^{\prime} \mathrm{W}$ Long). Possibly dates drainage of lake. Coll. 1968 by F. Byrne, Univ. of Wisconsin-Green Bay; subm. by R. A. Bryson.

\section{WIS-381. Jefferson County, Wisconsin}

$8540 \pm 85$

mound that has been built to height 8 or 9 ft abring mound that has been built to height 8 or $9 \mathrm{ft}$ above glacio-lacustrine plain on which it lies in Jefferson Co., Wisconsin $\left(42^{\circ} 52^{\prime} \mathrm{N}\right.$ Lat, $88^{\circ} 46^{\prime} \mathrm{W}$ Long). One of a number of like mounds id. in this general area, all developed on glacio-lacustrine floors. Coll. 1969 by F. Byrne; subm. by R. A. Bryson.

\section{Lake Mary and Stewart's Dark Lake, Wisconsin}

Sediment cores from centers of 2 meromictic lakes in Wisconsin, Stewart's Dark Lake (45 $18^{\prime} \mathrm{N}$ Lat, $91^{\circ} 27^{\prime} \mathrm{W}$ Long) and Lake Mary $\left(46^{\circ} 15^{\prime} \mathrm{N}\right.$ Lat, $89^{\circ} 54^{\prime} \mathrm{W}$ Long) obtained in 1962 by G. Likens, Dartmouth College, Hanover, New Hampshire; subm. by R. A. Bryson. Samples were dated to determine time of initiation of sedimentation in these meromictic lakes for which chemical analyses and diatom profiles have been reported (Likens, 1967). Complete pollen analyses are being undertaken for both these cores.

\section{WIS-371. Lake Mary, Wisconsin}

$9460 \pm 100$

Sample from 186 to $201 \mathrm{~cm}$ interval in $248 \mathrm{~cm}$ core, just above tilllake sediment interface.

\section{WIS-373. Stewart's Dark Lake, Wisconsin}

$$
10,280 \pm 105
$$

Sample from 603 to $612 \mathrm{~cm}$ level of $630 \mathrm{~cm}$ core; 613 to $630 \mathrm{~cm}$ level of core was glacial till.

\section{WIS-342. Wingra Fen, Wisconsin}

$$
8590 \pm 110
$$

Brown marl, sand, and organic matter with snail shells from Wisconsin Arboretum, $0.2 \mathrm{mi} \mathrm{S}$ of SW shore of Lake Wingra, Dane Co.,

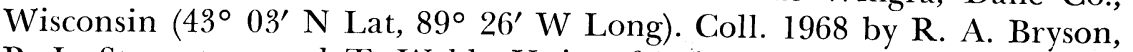
R. L. Steventon, and T. Webb, Univ. of Wisconsin-Madison; subm. by R. A. Bryson. Sample 1.7 to $1.8 \mathrm{~m}$ deep, $5 \mathrm{~cm}$ above pure white sand. Dates beginning of peat growth after lowering of level of Lake Wingra.

\section{WIS-353. Lake Mendota, Wisconsin}

Modern

85 to $95 \mathrm{~cm}$ portion of $95 \mathrm{~cm}$ core from Lake Mendota, Madison, Wisconsin ( $43^{\circ} 07^{\prime} \mathrm{N}$ Lat, $89^{\circ} 36^{\prime} \mathrm{W}$ Long). Material was dated to obtain a sedimentation rate (Murray, 1956) and hopefully date for beginning of cultural influence on drainage of Lake Mendota. Coll. 1966 by G. F. Lee and G. Bortelson, Univ. of Wisconsin-Madison; subm. by R. A. Bryson. 


\section{WIS-347. Mequon, Wisconsin}

$12,410 \pm 100$

10,460 в.c.

Larix root wood (id. by Forest Products Lab., Madison, Wisconsin) from $15 \mathrm{~cm}$ thick wood and peat layer contained within $3 \mathrm{~m}$ thick clay sequence that rested on glacial outwash (sand and gravel). Wood thought to represent deposit of Two Creeks age near terminal moraine of Valders ice. Sample from SW wall of sand pit, Mequon, Wisconsin $\left(43^{\circ} 15^{\prime} \mathrm{N}\right.$ Lat, $88^{\circ} 02^{\prime}$ W Long). Coll. 1965 by R. F. Black; subm. by L. J. Maher, Jr., Univ. of Wisconsin-Madison.

\section{B. Louisiana}

Investigations of Late Quaternary vegetational and climatic history of sites through North America were continued. Louisiana was searched for deep fossil organic accumulations which might allow comparisons with studies in Canada (Nichols, 1967), but deposits were shallow, largely minerogenic, and represented only short periods of Holocene. These materials were sampled with a modified Hiller-type borer which allowed removal of intact $4 \mathrm{~cm}$ diam. cores, $50 \mathrm{~cm}$ long, for examination in lab. Boring ceased when organic clays and silts became too stiff to penetrate. The deposits were waterlain; the reason for decreased organic content at their bases is unknown.

WIS-340. Lake Peigneur, Louisiana

$3750 \pm 65$

1800 B.C.

Organic silt from boring 220 to $230 \mathrm{~cm}$ deep of marshy edge of Lake Peigneur, Louisiana (29 $59^{\prime} \mathrm{N}$ Lat, $92^{\circ} 59^{\prime} \mathrm{W}$ Long). Coll. 1966 by H. Nichols and R. L. Steventon, Univ. of Wisconsin-Madison; subm. by $\mathrm{H}$. Nichols. Pretreatment by acid only.

\section{WIS-341. Big Woods Island, Louisiana}

$1710 \pm 55$

Wood peat with clay 180 to $190 \mathrm{~cm}$ below modern surface of swamp at Big Woods I., near Esther, Louisiana $\left(29^{\circ} 51^{\prime} \mathrm{N}\right.$ Lat, 92 ${ }^{\circ} 11^{\prime} \mathrm{W}$ Long). Coll. 1966 by H. Nichols and R. L. Steventon; subm. by H. Nichols. Acid pre-treatment only.

\section{Iowa}

Amos Ross site, Iowa (13PM16)

Samples coll. at Amos Ross site, Plymouth Co., Iowa $\left(42^{\circ} 37^{\prime} 30^{\prime \prime}\right.$ N Lat, $96^{\circ} 06^{\prime} 30^{\prime \prime} \mathrm{W}$ Long) and subm. 1968 by R. A. Bryson.

\section{WIS-322. Amos Ross site (13PM16)}

Black walnut (id. by B. F. Kukachka, Forest Products Lab.) from one of many stumps in situ rooted in paleosol ca. $10 \mathrm{ft}$ up side of deep gully. Stump buried under ca. $20 \mathrm{ft}$ of silt with well-developed soil horizons. Stratigraphy very similar to that reported by Daniels et al. (1963) for Harrison Co., Iowa. Stratigraphic position and date agree with $\mathrm{W}-702$, 2020 B.P. (Radiocarbon, 1960, v. 2, p. 145), at base of Hatcher formation. 
WIS-332. Amos Ross site (13PM16)

Charcoal from $12 \mathrm{ft}$ below modern surface. Date indicates wood probably from branches of black walnut, stumps of which were found $8 \mathrm{ft}$ below.

\section{Colorado}

\section{WIS-349. Molas Lake Bog}

$8890 \pm 90$

Detritus gyttja with wood fragments from bog $0.6 \mathrm{~km} \mathrm{~S}$ of $S$ entrance to Molas Lake, San Juan Co., near Silverton, Colorado $\left(37^{\circ} 45^{\prime} \mathrm{N}\right.$ Lat, $107^{\circ} 41^{\prime} \mathrm{W}$ Long). Site in subalpine vegetation zone of San Juan Mts. at elev. + $3230 \mathrm{~m}$. Sample from lowest organic sediments, 122 to 132 $\mathrm{cm}$ below modern surface, lay on cobbles and boulders of glacial origin. Plant remains in sample indicated aquatic environment when sediments accumulated. Should date retreat of local glacial ice. Wood at 60 to 70 cm depth, LJ-539, dated as $2990 \pm 300$ в.c. (Radiocarbon, 1963, v. 5, p. 271). Coll. 1960 and subm. by L. J. Maher, Jr., Univ. of WisconsinMadison.

\section{E. Canada}

Additional samples obtained from the base of peat bogs to provide minimum dates for deglaciation or start of ombrogenous peat growth (see Radiocarbon, 1968, v. 10, p. 477; Bryson and Wendland, 1967; and Nichols, 1969).

\section{WIS-323. Telford, Ontario}

$4030 \pm 75$

Exposed peat bank sampled by digging pit down to base. Total of ca. $350 \mathrm{~cm}$ peat over black and then blue clay with what appeared to be lake sands intercalated in upper horizons of peat. Sample 346 to $348 \mathrm{~cm}$ below modern peat surface. May represent withdrawal of Lake Agassiz from site. From Telford, near Kenora, Ontario $\left(49^{\circ} 51^{\prime} \mathrm{N}\right.$ Lat, $95^{\circ} 24^{\prime}$ W Long). Coll. 1967 and subm. by H. Nichols.

\section{WIS-329. The Bog at The Pas, Manitoba}

$610 \pm 60$

Very coarse oxidized woody fen peat, 142 to $147 \mathrm{~cm}$ below modern surface, immediately overlying marl. Coll. 1967 by R. A. Bryson and H. Nichols at The Bog, near The Pas, Manitoba $\left(53^{\circ} 15^{\prime} \mathrm{N}\right.$ Lat, $101^{\circ}$ $06^{\prime}$ W Long); subm. by H. Nichols.

\section{WIS-343. Entwhistle, Alberta}

$3550 \pm 65$

1600 B.C.

Black, crumbly, oxidized necron mud containing charcoal and $5 \mathrm{~mm}$ band of volcanic ash 154 to $156 \mathrm{~cm}$ below modern surface of peat bog at Entwhistle, Alberta, Canada (53 $35^{\prime} 30^{\prime \prime} \mathrm{N}$ Lat, $114^{\circ} 54^{\prime} 20^{\prime \prime} \mathrm{W}$ Long). Lowest organic sample (silty clay begins at $158 \mathrm{~cm}$ ) dates start of organic deposition in lake and dates volcanic ash horizon. Coll. 1968 by $\mathrm{H}$. 
Nichols, Univ. of Wisconsin-Madison, and J. A. Westgate, Univ. of Alberta, Edmonton; subm. by H. Nichols.

\section{F. Northwest Territories, Canada}

\section{Twin Lakes, Inuvik, N.W.T.}

Col. of peat, $410 \mathrm{~cm}$ deep, overlying gray clay, obtained in 1967 from Twin Lakes, Inuvik, Dist. of Mackenzie, N.W.T., Canada ( $68^{\circ} 22^{\prime}$ $\mathrm{N}$ Lat, $132^{\circ} 42^{\prime} \mathrm{W}$ Long). Sec. exhibited apparently horizontally continuous alternating layers of fibrous peat and Sphagnum mosses. Previous sample of peat from bottom of this bog (Mackay, 1963) was dated at 8200 \pm 300 в.P., GSC-25 (Radiocarbon, 1962, v. 4, p. 20). Coll. 1967 and subm. by J. C. Ritchie, Dalhousie Univ., Halifax, Nova Scotia.

WIS-279. Twin Lakes, Inuvik, N.W.T. $5420 \pm 70$

Sphagnum peat from 50 to $60 \mathrm{~cm}$ depth.

WIS-291. Twin Lakes, Inuvik, N.W.T.

$5840 \pm 65$ Fibrous woody peat from 120 to $130 \mathrm{~cm}$ depth.

3890 B.C.

WIS-310. Twin Lakes, Inuvik, N.W.T.

Woody, fibrous sedge peat from 270 to $290 \mathrm{~cm}$ below modern surface.

$$
\text { G. Peru }
$$

\section{Salinillas Lageon}

Excavations in midden on coastal cliff $6 \mathrm{~m}$ above modern sea level at Salinillas Lagoon, Salinas de Otuma, State of Ica, Peru $\left(14^{\circ} 00^{\prime} \mathrm{S}\right.$ Lat, $76^{\circ} 15^{\prime}$ W Long) carried out 1968 and subm. by N. Psuty, Univ. of Wisconsin-Madison.

\section{WIS-321. Salinillas Lagoon} near-terminal date for occupation of site and for change in ecologic environment of lagoon as result of uplift of coast.

\section{WIS-325. Salinillas Lagoon}

$$
3650 \pm 65
$$

(a) from surface. Outer $20 \%$ of shell removed by acid leaching. $\mathrm{C}^{14}$ content of shells from Peru coast is depleted by 3.5 to $8.5 \%$ compared to NBS standard (Taylor and Berger, 1967). $\delta \mathrm{C}^{13}$ compared to PDB stanclard $+0.2 \%$.

\section{WIS-330. Salinillas Lagoon}

Shell (Pecten purpuratus) stranded : on marine abrasion platform which rings Salinillas Lagoon. Because of $\mathbf{C}^{14}$ depletion in shells from this area (Taylor and Berger, 1967), we interpret the date as representing 
recent, rapid uplift of Otuma embayment. Undisturbed condition of valves suggests shell zone was not subjected to intense wave abrasion. Outer $20 \%$ of shell removed by acid leaching. $\delta \mathrm{C}^{13}$ compared to PDB standard $-0.4 \%$.

Date lists:

GSC I

La Jolla III

USGS $\mathrm{V}$

Wisconsin 1

Wisconsin $\mathrm{V}$

Wisconsin VI

\section{REFERENCES}

Dyck and Fyles, 1962

Hubbs, Bien, and Suess, 1963

Rubin and Alexander, 1960

Bender, Bryson, and Baerreis, 1965

Bender, Bryson, and Baerreis, 1968

Bender, Bryson, and Baerreis, 1969

Bell, R. E. and Baerreis, D. A., 1951, A survey of Oklahoma archaeology: Texas Archeol. and Paleont. Soc. Bull., v. 22, p. 8-100.

Bell, R. E., 1968, Dating the prehistory of Oklahoma: Great Plains Jour., v. 7, no 2, p. $1-11$

Bender, M. M., 1968, Mass spectometric studies of carbon 13 variations in corn and other grasses: Radiocarbon, v. 10, p. 468-472.

Bender, M. M., Bryson, R. A., and Baerreis, D. A., 1965, University of Wisconsin radiocarbon dates I: Radiocarbon, v. 7, p. 399-407.

- 1968, University of Wisconsin radiocarbon dates V: Radiocarbon, v. 10, p. $473-478$. p. $228-235$.

Brown, C. E., 1906, A record of Wisconsin antiquities: The Wisconsin Archaeologist, o.s., v. 5 , no. $3-4$, p. 364

Bryson, R. A. and Wendland, W. M., 1967, Radiocarbon isochrones of the retreat of the Laurentide ice sheet: Tech. Rept. 35, ONR 1202(07), Univ. of Wisconsin, Dept. of Metcorology.

Daniels, R. B., Rubin, M., and Simonson, G. H., 1963, Alluvial chronology of Thompson Creek watershed, Harrison County, Iowa: Am. Jour. Sci., v. 261, p. 473-487.

Dyck, W. and Fyles, J. G., 1962, Geological survey of Canada radiocarbon dates I: Radiocarbon, v. 4, p. 13-26.

Hubbs, C. L., Bien, G. S., and Suess, H. E., 1963, La Jolla natural radiocarbon measurements III: Radiocarbon, v. 5, p. 254-272.

Likens, G. E., 1967, Some chemical characteristics of meromictic lakes in North America, in: D. Jackson (ed.), Some aspects of meromixis, Syracuse Univ., N.Y., p. $17-62$.

Mackay, J. R., 1963, The MacKenzie Delta area, N.W.T., Mem. 8, Geog. Branch, Ottawa.

Murray, R. C.. 1956, Recent sediments of three Wisconsin lakes: Geol. Soc. America Bull. v, 67, p. 883-910.

Nichols, H., 1967, The post-glacial history of vegetation and climate at Ennadai Lake, Keewatin, and Lynn Lake, Manitoba: Eiszeitalter und Gegenwart, v. 18, p. 176-197. - 1969, Chronology of peat growth in Canada: Palaeogeog., palaeoclimat. palaeoecol., v. 6, p. 61-65.

Rubin, M. and Alexander, C., 1960, U.S. Geological Survey radiocarbon dates V: Am. Jour. Sci. Radiocarbon Supp., v. 2, p. 129-185.

Tavlor, R. E. and Berger, R., 1967, Radiocarbon content of marine shells from the Pacific coasts of Central and South America: Science, v. 158, p. 1180-1182.

Wittry, W. L., 1959, Archeological studies of four Wisconsin rockshelters: The Wisconsin Archeologist, v. 40, no. 4, p. 137-267. 